\title{
Comparative analysis of soil infiltration under three types of land use Jianwei Yun ${ }^{1, ~ a, ~ Q i n g q i n g ~ K o u ~}{ }^{2, b}$ and Weihua Zhang ${ }^{3, c}$ \\ $1,2,{ }^{3}$ College of Resources \& Environment, Southwest University, Chongqing, China a371284646@qq.com, bkqinger@126.com, cswuwater@126.com
}

Keywords: Steady infiltration rate; Grass infiltration apparatus; Saturated moisture content; Bulk density

Abstract. It is of great significance to understand the rule of soil infiltration to develop and better use of land resources or guide the agricultural irrigation. The grass infiltration apparatus is used to test the soil infiltration under different land uses, including grassland, woodland and vegetable land. The relationship between saturated water content and bulk density and their influence on soil infiltration were studied also. The main results are as follows: 1)The steady infiltration rate of grassland, woodland, and vegetable land soil are $1.87 \mathrm{~mm} / \mathrm{min}, 0.39 \mathrm{~mm} / \mathrm{min}, 6.93 \mathrm{~mm} / \mathrm{min}$ respectively; The saturated moisture content are $23.41 \%, 27.53 \%$ and $28.78 \%$ respectively; The soil bulk density was $1.61 \mathrm{~g} / \mathrm{cm}^{3}, 1.46 \mathrm{~g} / \mathrm{cm}^{3}$ and $1.43 \mathrm{~g} / \mathrm{cm}^{3}$ respectively.2)The steady infiltration rate and saturation moisture content are positively correlated. 3)The weight of soil is negatively correlated with the saturated moisture content. These results can provide useful information for land improvement, water and soil management practices.

\section{Introduction}

The rapid economic development, people's living level gradually improve, however, water shortage, water quality deterioration, land degradation and environmental deterioration and other issues has seriously affected the economic development and social stability of our country, how to solve the shortage of water and soil resources and the deterioration of agricultural sustainable development in our country has important significance[1-5].To improve the utilization of rainwater resources and make full use of the limited water resources, the development of low-water agriculture has become an international subject[6-9].

Soil infiltration is the process of liquid water entering the soil, which is an important link in the natural water cycle[10]. The infiltration rate of soil is determined by the degree of moisture and porosity of the soil. For example, the soil infiltration capacity of dry, coarse texture and good structure is strong, whereas the infiltration capacity is weak[11].It is of great practical significance to study how the soil infiltration performance can reduce rainfall, increase infiltration, and reduce surface runoff to soil erosion.

According to the soil infiltration law of different land use mode research, scholars in our country mostly adopts double loop method, artificial rainfall, hydrological method, etc.[12], it is rare to see someone with grass infiltration apparatus for determination of rainfall infiltration.It is a good choice to measure soil permeability in the field because it is convenient to carry and easy to operate.In this paper,it will use grass infiltration apparatus measuring infiltration law of soil under different land use modes, and analyzes the relationship between saturated moisture content and bulk density and their influence on infiltration condition, verify whether the conclusions are consistent.

\section{Materials and methods}

The soil in the soil of grassland, woodland soil and vegetable soil were soil, and the basic situation was shown in table 1 . 
Table 1 The basic situation of the soil used for testing

\begin{tabular}{|c|c|c|c|c|c|c|}
\hline Land use mode & Sampling point & $\begin{array}{l}\text { Latitude and } \\
\text { longitude }\end{array}$ & altitude & $\begin{array}{c}\text { Air } \\
\text { pressure }\end{array}$ & slope & $\mathrm{pH}$ \\
\hline \multirow{3}{*}{ grassland } & $\left(\mathrm{P}_{1}\right)$ & $\begin{array}{c}29^{\circ} 48^{\prime} 50^{\prime \prime} \mathrm{N} \\
106^{\circ} 24^{\prime} 44^{\prime \prime} \mathrm{E}\end{array}$ & $190.3 \mathrm{~m}$ & $985.9 \mathrm{hPa}$ & $0^{\circ}-1^{\circ}$ & \multirow{3}{*}{5.54} \\
\hline & $\left(\mathrm{P}_{2}\right)$ & $\begin{array}{c}29^{\circ} 48^{\prime} 49^{\prime \prime} \mathrm{N} \\
106^{\circ} 24^{\prime} 44^{\prime \prime} \mathrm{E}\end{array}$ & $190.2 \mathrm{~m}$ & $985.9 \mathrm{hPa}$ & $0^{\circ}-2^{\circ}$ & \\
\hline & $\left(\mathrm{P}_{3}\right)$ & $\begin{array}{c}29^{\circ} 48^{\prime} 50^{\prime \prime} \mathrm{N} \\
106^{\circ} 24^{\prime} 44^{\prime \prime} \mathrm{E}\end{array}$ & $209.9 \mathrm{~m}$ & $986.0 \mathrm{hPa}$ & $0^{\circ}-2^{\circ}$ & \\
\hline \multirow{3}{*}{ woodland } & $\left(\mathrm{P}_{1}\right)$ & $\begin{array}{c}29^{\circ} 49^{\prime} 06^{\prime \prime} \mathrm{N} \\
106^{\circ} 24^{\prime} 49^{\prime \prime} \mathrm{E}\end{array}$ & $231.1 \mathrm{~m}$ & $981.3 \mathrm{hPa}$ & $0^{\circ}-1^{\circ}$ & \multirow{3}{*}{5.21} \\
\hline & $\left(\mathrm{P}_{2}\right)$ & $\begin{array}{l}29^{\circ} 49^{\prime} 06^{\prime \prime} \mathrm{N} \\
106^{\circ} 24^{\prime} 50^{\prime \prime} \mathrm{E}\end{array}$ & $230.0 \mathrm{~m}$ & $981.3 \mathrm{hPa}$ & $0^{\circ}-2^{\circ}$ & \\
\hline & $\left(\mathrm{P}_{3}\right)$ & $\begin{array}{c}29^{\circ} 48^{\prime} 48^{\prime \prime} \mathrm{N} \\
106^{\circ} 24^{\prime} 41^{\prime \prime} \mathrm{E}\end{array}$ & $231.7 \mathrm{~m}$ & $984.2 \mathrm{hPa}$ & $0^{\circ}-8^{\circ}$ & \\
\hline \multirow{3}{*}{ vegetable land } & $\left(\mathrm{P}_{1}\right)$ & $\begin{array}{c}29^{\circ} 49^{\prime} 11^{\prime \prime} \mathrm{N} \\
106^{\circ} 24^{\prime} 49^{\prime \prime} \mathrm{E}\end{array}$ & $272.5 \mathrm{~m}$ & $981.6 \mathrm{hPa}$ & $0^{\circ}-1^{\circ}$ & \multirow{3}{*}{5.99} \\
\hline & $\left(\mathrm{P}_{2}\right)$ & $\begin{array}{c}29^{\circ} 49^{\prime} 11^{\prime \prime} \mathrm{N} \\
106^{\circ} 24^{\prime} 49^{\prime \prime} \mathrm{E}\end{array}$ & $272.6 \mathrm{~m}$ & $981.7 \mathrm{hPa}$ & $0^{\circ}-2^{\circ}$ & \\
\hline & $\left(\mathrm{P}_{3}\right)$ & $\begin{array}{c}29^{\circ} 49^{\prime} 11^{\prime \prime} \mathrm{N} \\
106^{\circ} 24^{\prime} 49^{\prime \prime} \mathrm{E}\end{array}$ & $272.5 \mathrm{~m}$ & $981.6 \mathrm{hPa}$ & $0^{\circ}-2^{\circ}$ & \\
\hline
\end{tabular}

In this paper, the saturated water content and bulk density of grassland, woodland and vegetable land were determined by drying method. The infiltration test was carried out in the field with Turf-Tec grass infiltration apparatus, its calculation formula is as formula (1).

$$
f_{0}=\frac{h_{0}}{t_{0}}
$$

In formula: $f_{0--}$ initial infiltration rate $(\mathrm{mm} / \mathrm{min}) ; h_{0}--$ infiltration water level $(\mathrm{mm}) ; t_{0}--$ infiltration time(min).

\section{Results and discussion}

\section{The infiltration results}

The characteristic curve of soil water infiltration is shown in figure 1.

The initial infiltration rates of grassland, woodland and vegetable soil were $8.07 \mathrm{~mm} / \mathrm{min}$, $6.50 \mathrm{~mm} / \mathrm{min}$ and $45.67 \mathrm{~mm} / \mathrm{min}$ respectively. The time of soil stabilization in grassland, woodland and vegetable soil was $100 \mathrm{~min}, 80 \mathrm{~min}$ and $80 \mathrm{~min}$ respectively.Their infiltration rates were $1.87 \mathrm{~mm} / \mathrm{min}$, $0.39 \mathrm{~mm} / \mathrm{min}$ and $6.93 \mathrm{~mm} / \mathrm{min}$ respectively. Visible on the test, the penetration of vegetable is the best, followed by the grass, finally the woodland, its steady infiltration rate is minimum, shows that woodland has the best capacity for water conservation(Fig.1).

\section{The relationship between saturated water content, bulk density and steady infiltration rate}

The results of saturated water content and bulk density of the three kinds of land use modes soil are shown in table 2. 
Table 2 The analysis of soil steady infiltration rate, saturated moisture content and bulk density in grassland, woodland and vegetable land soil

\begin{tabular}{cccc}
\hline Land use mode & $\begin{array}{c}\text { steady infiltration rate } \\
(\mathrm{mm} / \mathrm{min})\end{array}$ & $\begin{array}{c}\text { saturated moisture content } \\
(\%)\end{array}$ & $\begin{array}{c}\text { bulk density } \\
\left(\mathrm{g} / \mathrm{cm}^{3}\right)\end{array}$ \\
\hline grassland & 1.87 & 23.41 & 1.61 \\
woodland & 0.39 & 27.53 & 1.46 \\
vegetable land & 6.93 & 28.78 & 1.43 \\
\hline
\end{tabular}

The fitting curve of the relationship between saturated water content and steady infiltration rate of three kinds of land use modes soil is shown in Fig.2,the relationship between bulk density and steady infiltration rate is shown in Fig 3,the relationship between bulk density and saturated water content is shown in Fig.4.
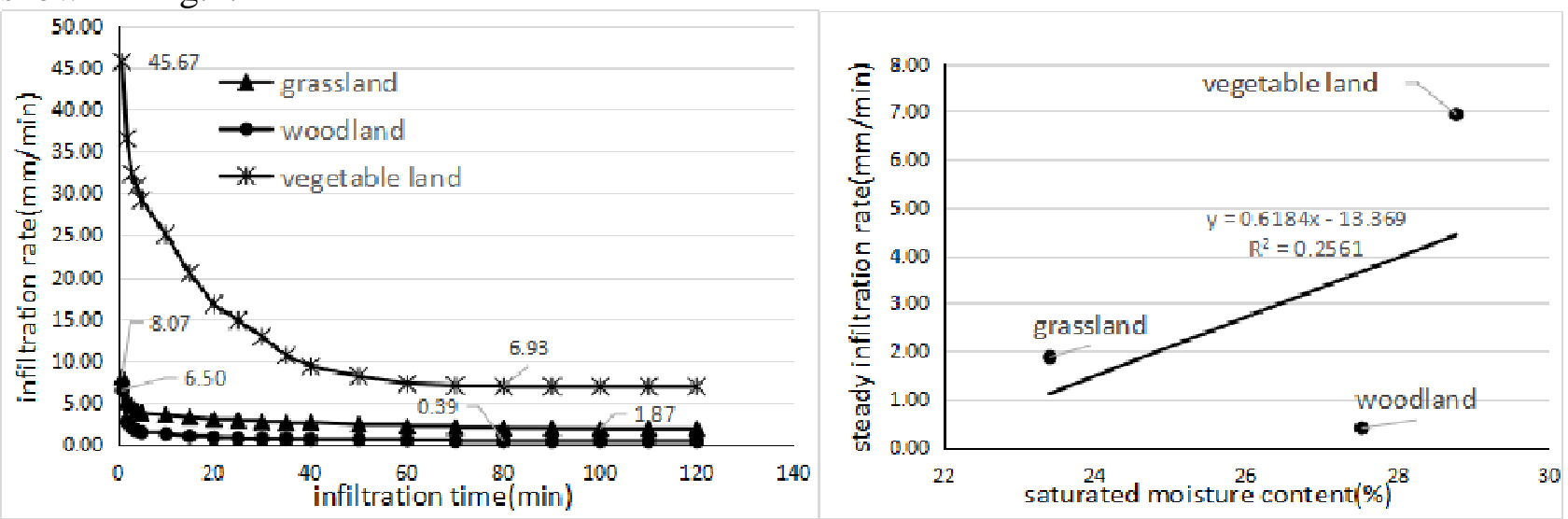

Fig.1. Soil moisture infiltration characteristic curve of grassland, woodland and vegetable land soil

Fig.2. The relationship between saturated water content and steady infiltration rate of three kinds of land use modes soil

The steady infiltration rate is positively correlated with the saturated moisture content, and the saturated water content is high in the soil moisture permeability and soil moisture retention capacity, which is beneficial to water infiltration.But the correlation between the two is not high,the reason of this is that the soil type is less, and the rate of stability is higher.And we found there are more stones under the grass in the process of field experiment, it leads to the grassland soil porosity is larger, so there may be downstream in the process of infiltration water channel leads to steady infiltration rate is bigger(Fig.2).
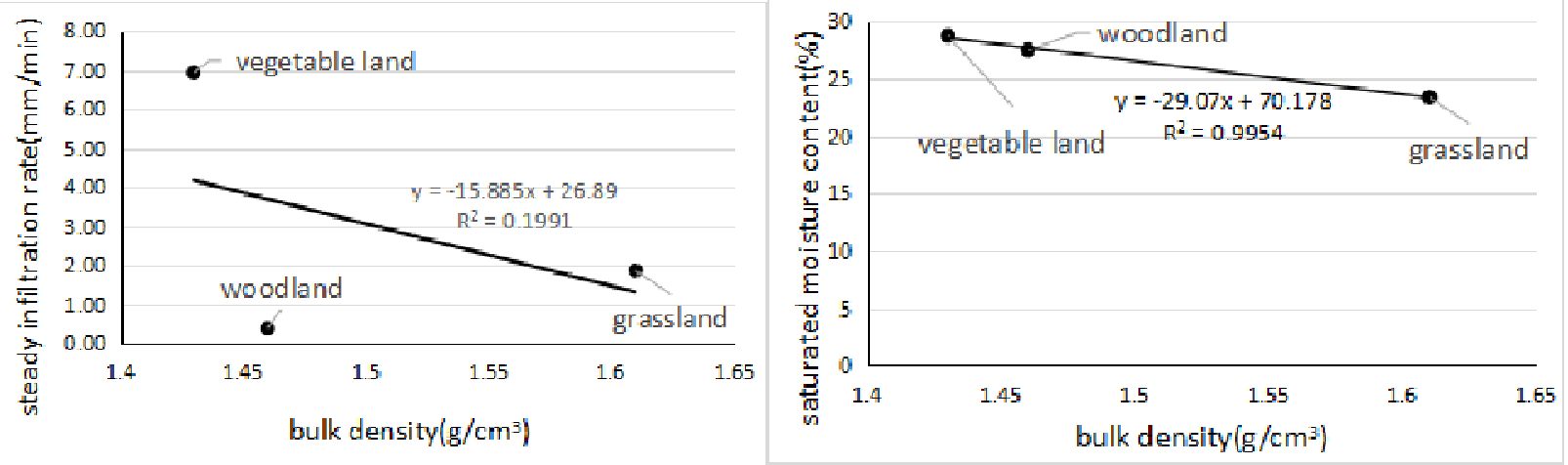

Fig.3. The relationship between bulk density and steady infiltration rate of three kinds of

Fig.4. The relationship between saturated water content and saturated water content of three kinds of land use modes soil land use modes soil

Steady infiltration rate has negatively correlated with bulk density, because small soil bulk density, soil porosity, accordingly its penetration ability is strong(Fig.3). 
There is a negative correlation between soil bulk density and saturated water content.Some studies have shown that the soil with higher bulk density has a relatively small porosity, and the water conductivity of soil is weakened accordingly.This is consistent with the results of this experiment(Fig.4).

\section{Conclusions and recommendations}

The experiment results show that:1)The steady infiltration rates of grassland, woodland and vegetable soil were $1.87 \mathrm{~mm} / \mathrm{min}, 0.39 \mathrm{~mm} / \mathrm{min}$ and $6.93 \mathrm{~mm} / \mathrm{min}$ respectively;2)The steady infiltration rate and saturation moisture content are positively correlated..The weight of soil is negatively correlated with the saturated moisture content.

And put forward two Suggestions.

1)The water head pressure is present in the determination of soil infiltration law by the sod, which results in the determination of the infiltration rate higher than the actual value, and how to eliminate this effect is still to be further studied.

2)Turf infiltration meter compared with double ring infiltration apparatus more convenient to carry, operating more simple, but through the literature found that now there are few scholars use grass infiltration apparatus measuring soil infiltration, so the future can promote grass infiltration apparatus used to measure soil water infiltration.

\section{Acknowledgements}

This work was financially supported by Chongqing Research Program of Basic Research and Frontier Technology, No. cstc2016jcyjA0460

\section{References}

[1] Deng X.P, Shan L, Zhang H.P: Improving agricultural water use efficiency in arid and semiarid areas of China.Agricultural Water Management, 80(206)p23-40.

[2] Han H.Y, Jeff BB:China's agricultural water resources utilization in the 21st century. Agricultural and rural development,11(2002)p4-7.

[3] Chen X.L, Fang T.K:Analysis on the current situation of agricultural water use management in China. Agricultural and rural development, 4(2006)p39-40.

[4] Hu J.L, Wang S.C, Yeh F.Y:Total-factor water efficiency of regions in China.Resource Policy, 14(2007)p217-230.

[5] Mvungi, Mashauri D, Madulu N.F:Management of water for irrigation agriculture in semi-arid areas: Problems and prospects. Physics and Chemistry of the Earth, Parts A/B/C, 30(2005)p809-817.

[6] Li S.X: China's dry land agriculture. China agricultural press.(2004)

[7] Bagarello V, Elrick D, EIovino M:laboratory analysis of falling head infiltration procedures for estimating the hydraulic conductivity of soils. Geoderma, 135(2006)p322-334.

[8] Khare D, Jat MK, Ediwahyunan: Assessment of counjunctive use of planning options: A case study of Sapon irrigation command area of Indonesia. Journal of Hydrology, 328(2006)p764-777.

[9] Feng S, Li L.X, David AG: Assessing the impacts of South to North Water Transfer Project with decision support systems. Decision Support systems, 42(2007)p1989-2003.

[10] Yuan J.P, Lei T.W, Guo S.Y: Study on spatial variation of infiltration rates for small watershed in loess plateau. Journal of water conservancy, 10(2001)p88-92. 
[11] Gong Z.P, Shao X.H, Zhang F.B: Soil science and agriculture. China water conservancy and hydropower press.(2009)

[12] Zhou B. Analysis of the double-loop infiltration of grassland soil. Biotechnology world,06(2015)P2. 